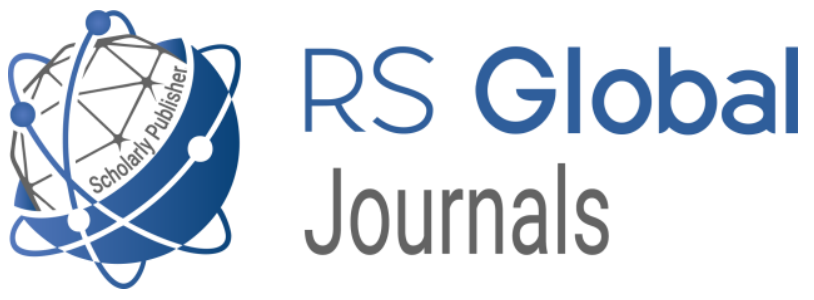

Scholarly Publisher

RS Global Sp. z O.O.

ISNI: 0000000484952390

Dolna 17, Warsaw, Poland 00-773

Tel: +48226022703

Email: editorial_office@rsglobal.pl

JOURNAL International Journal of Innovative Technologies in Social Science

p-ISSN

$2544-9338$

e-ISSN

2544-9435

PUBLISHER

RS Global Sp. z O.O., Poland

ARTICLE TITLE

LANGUAGE AND STYLE PROBLEMS OF TRANSLATION OF JORGE GORDON BYRON'S "EASTERN POEMS" INTO AZERBAIJANI LANGUAGE

$\operatorname{AUTHOR}(\mathbf{S})$

Minaya Mammadova

Minaya Mammadova. (2021) Language and Style Problems of Translation of Jorge Gordon Byron's "Eastern Poems" Into

ARTICLE INFO Azerbaijani Language. International Journal of Innovative Technologies in Social Science. 4(32). doi:

10.31435/rsglobal_ijitss/30122021/7697

DOI

https://doi.org/10.31435/rsglobal_ijitss/30122021/7697

RECEIVED

04 October 2021

ACCEPTED

22 November 2021

PUBLISHED

26 November 2021

LICENSE

This work is licensed under a Creative Commons Attribution

4.0 International License.

(C) The author(s) 2021. This publication is an open access article. 


\title{
LANGUAGE AND STYLE PROBLEMS OF TRANSLATION OF JORGE GORDON BYRON'S "EASTERN POEMS" INTO AZERBAIJANI LANGUAGE
}

\author{
Minaya Mammadova, Teacher, Azerbaijan State Pedagogical University, Azerbaijan
}

DOI: https://doi.org/10.31435/rsglobal_ijitss/30122021/7697

\section{ARTICLE INFO}

Received 04 October 2021

Accepted 22 November 2021

Published 26 November 2021

\section{KEYWORDS}

J.G. Byron, translator, phrase, artistic figure, phraseological unit, characteristic, poetic language, thinking.

\begin{abstract}
On the one hand, the image of the translated examples of "Oriental Poems" gives a full picture of the talent of J.G. Byron, on the other hand, it clarifies the talent and ability of the translator in the field of translation, the use of language, its poetic layer, richness of phrases. The expressiveness created by artistic figures, phraseological combinations, as well as fixed word patterns, shows a perfect fullness at the level of speech etiquette within the text. Phraseological units come to the fore as a component of imagery and a means of providing it throughout the text.
\end{abstract}

Citation: Minaya Mammadova. (2021) Language and Style Problems of Translation of Jorge Gordon Byron's "Eastern Poems" Into Azerbaijani Language. International Journal of Innovative Technologies in Social Science. 4(32). doi: 10.31435/rsglobal_ijitss/30122021/7697

Copyright: (C) 2021 Minaya Mammadova. This is an open-access article distributed under the terms of the Creative Commons Attribution License (CC BY). The use, distribution or reproduction in other forums is permitted, provided the original author(s) or licensor are credited and that the original publication in this journal is cited, in accordance with accepted academic practice. No use, distribution or reproduction is permitted which does not comply with these terms.

Introduction. Jorge Gordon Byron, one of the luminaries of world literature, said, "The study of the language and stylistic features of the translation of Eastern poems into Azerbaijani is especially relevant at all levels. It is important to convey the syntactic figures in the translation, and in the translator's possibilities it is important to pay attention to what indicators. As it is known, in the artistic environment, phraseological units are ready-made poem templates, poetic language component, the most successful provider of art within the text, ready-made poem and so on. interpret in meanings. In general, the specificity of the art of poetry is determined by its sensory and intellectual thinking. Phraseological units, phraseological word combinations, phraseologically stable expressions and phrases clarify the richness of language and the artist's ability to use it as an invaluable provider of artistic flow in the text of the poem. By attaching itself to the richness of a kind of vernacular, it is also loaded with a serious imagination as a carrier of the soul. As it is known, the best works of art reveal the inner essence of the vernacular, the level of possibility and aesthetics.

Poetry is an indicator of the freshness and freshness of the language. All the possibilities and indicators of the vernacular as a whole manifest themselves more clearly and vividly in the literary text. The connection between the tone of voice and the inner harmony serves to create a miracle of language in phraseological units, in general, in syntactic figures. Explains the incredible richness in the content (internal semantics) of phrases that are inexhaustible and bound to the idea of the infinity of its boundaries. Colorful artistic and aesthetic layers, stylistic findings draw attention to their mobility within the text. Fixed word combinations also acquire stylistic meanings by creating a figurative idiomatic environment at all levels.

Stylistic features of the translation of JG Byron's "Oriental Poems" into Azerbaijani. The outstanding representative of English literature J.G. Byron's work and the stylistic features of the translation of his works into the Azerbaijani language reflect the colorful qualities of phraseological language materials. It should be added that "at all times, phraseological combinations have been 
valued by literary critics as a means of figurativeness, high expressiveness, rather than an ordinary lexical unit. It should also be emphasized that folk phraseology has a leading position in this regard" [123, 158]. In world literature, "beloved poet", "Byronism", "contradictory-individualism", "rebellious spirit" and so on. The work of J.G. Byron, mentioned under the names, has risen to this inaccessibility in the common language and thought. The rich language of his works has become inaccessible by connecting them to the vernacular and by focusing on the cultural ideas of the ethnos as a whole. "Gavur", "Siege of Corinth", "Prisoner of Chilion", "Mazepa", "Cain", "Bride of Abydos" and others. His works are a clear indication of this, and are perfectly connected in the translation and in the original. It is interesting that in the translation into Azerbaijani, all artists are committed to revealing the essence of the name "favorite poet" by showing loyalty to it.

In the translation of J.G. Byron's poetry, phraseological units are characterized by a serious imagination as the most typical example of folk wisdom in all contexts. Adds warmth and additional tone to the poetic feelings of the artist within the text. Throughout the work, the poet reveals his creative potential, his ability to use the richness of oral folk literature with high skill, the unique freshness of his artistic example. It should be added that the ability of phraseological combinations in the text environment is directly related to the capabilities of the poet and his ability to benefit from the richness. Here, the artistic level of the word, its aesthetic function, the breadth of the expressed idea give an idea of the success of the work as a component of the integrity of the text. "Successful use of the phraseological unit makes it clear that the poetic thinking of literary figures draws its strength from natural sources, the figurative thinking of the people, and phraseological combinations benefit from this powerful foundation and play a stimulating role in the emergence of brilliant imagery" [55, 376-377]. In general, phraseological units come to the fore as a component of imagery and a means of providing it throughout the text. Rather, figurativeness is in the nature of phraseological combinations.

Free expressions that gain expression in the poet's separate works ("there is also a shadow to open and empty" [p.13], "Who's in that green dress ahead?" [p.23], "He is known by his yellow hat, he is" [p.30] etc., is based entirely on the creation of content with a phonopoetic, morphopoetic layer, the delivery of its poetic nuances, aesthetic power. Free and stable associations such as "Gavur", "The Siege of Corinth", "Prisoner of Chile", "Mazepa", etc., play an important role in the delivery of art in terms of translation of works. The expressiveness created by artistic figures, phraseological combinations, as well as fixed word patterns, shows a perfect fullness at the level of speech etiquette within the text. The intensity of processing of this group of words (phraseological combinations) provides additional food in translation. Therefore, phrases as components of art are rooted in meaning in all contexts with their charm, poetic imagination and sincerity in the artistic flow.

"Oriental poems" are characterized by the poetic possibilities of the word and its functional character in the text. A literary word is a phenomenon of speech that seems to be able to reflect such a polished, wonderful and colorful content that its essence can be revealed only in the shades of meaning that it reflects within the text. As is well known, the poetic function of a word differs from its usual function, because in the poetic sphere the artistic pattern acquires a new content by being loaded with the linguistic components of poetics itself. "Words and expressions, which are the product of poetic thinking, can become the material of ordinary (informative) thinking ... Phraseologisms were also created due to the poetic capabilities of language, but now they are among the normative units of language. The poetic function of the word is reminiscent of the poetic function of sound (sound of music), color. There is a whole field of art in words, which we call the art of words or literature" [51, 26-27]. In general, in art, the poetic function of the word and the poetic function of sound and color appear in order to exhibit the same purpose.

Translations by B. Vahabzade, A. Aslanov, I. Rahimov, N. Ganjali, A. Rza from J.G. Bayron, one of the prominent representatives of world literature, appear at the level of standing alone with the original within the boundaries of the poetic word. For example, "live, kiss the owner" [p.28], "he speaks like ... I never cry" [p.40], "I have never sighed or cried in my life" [p.47], "he has seen, the dog of absence finger" [p.14], "where are the unprinted rams" [p.16], "Hasan will not listen here" [p.21], "maybe he was bent ... his eyes were full" [p.50] and so on., in verses, the load of thought adds extra food to the text by tuning in to the figurative expression. In the translated texts, it clarifies the dynamic picture of what comes from the translation itself and the essence of the people.

Phrases as a folk level of poetic cognition. Phrases are linguistic facts that reveal the people's level of poetic cognition. The language components that underlie the ability to feel and speak as a 
people were invaluable in terms of reflecting national color. For the work of J.G. Byron, they are of great importance in terms of creative quality, individual style. For example, "he would not fight; full of heart, full of eyes" [p.154], "no one believed this white lie" [p.155], "our heads do not open because of love" [p.157, p.167], "my teeth cut my gut in anger" [p.167], "darkness persisted, darkness stood on my face" [p.171], "maybe I thought it was black" [p.175], "steel will, I had endurance" [p.151], "he enslaved his pain to his will" [p.151], "this is the work of a hard day, hard work" [p.151], "we catch fire, we look at matter" [p.168], "We longed for a stranger, a lonely shore" [p.169], "he was so mad, a tired horse, I said it would explode at this hour" [p.171], "there is a man, his soul gathers in the dirt" [p.172] "to his dream, give it to him" [p.173] and so on. In the richness of poetic figures, the success of literary translation in the original and in the example of translation emerges. On the one hand, the image of the translations of "Oriental Poems" gives a full picture of the talent of C.Q. Byron, on the other hand, it clarifies the talent and ability of the translator in the field of translation, the use of language, its poetic layer, richness of phrases.

The artistic principle of the traditional style is in a variety of words; in fixed and free word combinations, repetitions, artistic question, speech, epithet, exaggeration, metanimia, metaphor, synecdoche, inversion, sound associations, it is integrated as a thought code in the historical development diachrony of syntagmatic structure. Phraseological combinations were invaluable in characterizing the stylistic and aesthetic function of the language of poetry, in tuning into new content (or shades of content) within the context, and in displaying an environment of impact and delivery of thought. Phrases within the text highlight the grandeur of the spoken language. It is distinguished by its special function in terms of creating wide opportunities for the expression of artistic thought. Therefore, phrases are analyzed as ready-made literary language material. As it is known, "if a writer (poet) sees the tendency of artistic and aesthetic development of the period and is able to rise to that level, perceives and follows the literary process, and at the same time manages to break and collect the guiding light of this tendency and process in his personal creative lens is an artist. It is the ability to connect the individual with the general that they really earn only through mastery" [50, 242]. The analysis of the translation of some examples from the works of A. Aslanov, B. Vahabzade, I. Rahimov, N. Ganjali, A. Rza into the Azerbaijani language from the works of J.G. Bayron, one of the great figures of world literature, forms a magnificent image in the example of art.

The imagination created by phraseological words, expressions and phrases in all examples of translation, as an example of a kind of artistic talent, becomes an important factor in ensuring poeticity, as well as adding extra food to the text. Because among the ready poetic figures, the phrases connected with the rich linguistic intellect of the people, as an example, have a special function in the expression of expressiveness, emotionality, artistic and aesthetic integrity. Stable and free word combinations, as one of the most perfect sources of poetry, create a wide range of artistic patterns with colorful stylistic shades. The semantic memory of the word contributes to a kind of textual phenomenon, the success of the genre content. Proceeding from the tendencies of artistic and aesthetic development of the period, J.G. Byron formed an inaccessible creative peak with "Oriental Poems", the idea of the perfection of artistic thought. Realized by its rich language and facts of thought, this greatness was the basis for the establishment of connections in both the East and the West.

The imagination created by the translation and the original, the mobility and perception of mythological and historical memory, the creative erudition and the ability to study ethnic culture as a whole revealed the talent of J.G. Byron. For example, "I had enough patience until I died" [p.173], "my heart was troubled by doubt" [p.174], "my eyes were suddenly annoyed" [p.175], "the lips of a Cossack beauty ran away" [p.175], "I must not cut a word, I must not listen" [p.175], "my dream has come to my throne tonight" [p.154], etc., as a whole, ensure the success of phraseological combinations in obtaining the text. All this clarifies the frequency of development of phraseological combinations and the semantic function of the imagination expressed in the text, its connection with broad and deep semantics.

He equates man and animal.

This brew under the old oak. [23, 152]

A light filters through our eyes

Dinner was a rare meal.

Zuleykhan's tender eyes are this brew

He touched the flowers in the pot. [23, 64] 
Or:

Selim locked his lips. [23, 57]

Consider another example:

It remained in his heart.

A rebellion shining in his eyes

Parsley scared this time,

Capture to win Selim's heart. $[23,57]$

These patterns, polished with colorful poetic figures, are connected with the point of development of the phrases and the poetic nature of the text, with a perfect imagination, with the linguistic originality of the artist's talent. The fact that Zuleykhan's gentle eyes touch the flowers in the pot, Selim's lips are locked, the rebellion shines in his eyes, his heart is captured, etc., clarifies the grandeur of the texture of the language in the text of such poetic figures.

Conclusions. In the emotional function of language, the content covered by phraseological combinations comes to the fore with important qualitative indicators to convey the artist's individuality, the author's subjective world, his views. The unique talent of J.G. Byron was taken as a goal in the translation of "Oriental Poems" into the Azerbaijani language and was rooted in the artist's expression as a whole. The mystery created by the creative genius, feelings and emotions in the literary text is listed as an element of perfection in the general flow of episodes and events. Phrases come to the fore with an emotional nature in terms of sensitivity to the environment, the object and event described, and the essence of the subject presented. All this is due to the desire to convey the wishes of the artist, his thoughts, to express the author at the level of translation.

\section{REFERENCES}

1. Agayev Z. Foreword. C.Q. Bayron. Selected works / Z. Agayev. - Baku: East-West, -2006. - s. 4-8.

2. Agayeva İ.S. Artistic and scientific style / - Baku: Maarif, - 1988. - 168 p.

3. Agayeva R. The role of extra-linguistic factors in the formation of phraseology: / dissertation for doctorate in philology / -Baku: AUL, - 2016. -158 p.

4. Azerbaijan literary linguistic style. Essays / -Baku: Science, -1970. -365 p.

5. Byron J.G. Poems of the East / C.Q. Byron. - Baku: Ushaqganjnashr, - 1959. - 196 p.

6. Byron J.G. Selected works / C.Q. Byron. - Baku: East-West, -2006. - 224 p.

7. Leslie A. Marchand. Byron's Poetry. (a critical instroduction). Rutgers-The State University Boston, 1965. - 478 p.

8. Byron. The Poetical works of lord Byron / London, Oxford University Press, - 1912. - 924 p.

9. Щвейцер А.Д. Перевод и лингвистика / А.Д. Щвейцер. - Москва Воениздат, - 1973. - 280 с.

10. Комисаров В.Н. Лингвистика перевода / В.Н. Комисаров. - Москва, Международные отношения, 1980. - $216 \mathrm{c}$. 